\title{
GREENING AS AN ELEMENT OF SUSTAINABLE URBAN DEVELOPMENT: VALUATION OF ECONOMIC FEASIBILITY, POLICYASSESSMENT AND PRACTICAL EXAMPLES
}

\author{
I. Alekseeva, D. Menshikh, O.V. Kudryavtseva \\ Moscow State University \\ Leninskie gori str., 1, building 46, Moscow, Russia, 119991
}

\begin{abstract}
The article reveals the importance of urban greening as a part of sustainable urban development concept. We examinethe ecological, social, cultural, spatial benefits of urban greening promotionas well as the possible constrains to urban space vegetating. It is shown that the assessment of tree benefits can be important for implementation of sustainable urban development. In turn,appropriate urban greening assessment is also important. The article provides existing urban greening assessment methods and their implementation in real-life practices.
\end{abstract}

Key words: sustainable urban development, urban greening, green space change, urban challenges and problems

\section{INTRODUCTION}

Sustainable development has been a subject of active scientific research in recent years $[5 ; 11 ; 22]$. The sustainable development is the interdependence of environmental, economic and social issues in the process of human development, initially its basic principles were discussed at the United Nations Conference on the Human Environment [42]. The conference's declaration pointed out that while economic and social development is essential for the improvement of the quality of life, "the protection of the human environment is amajor issue which affects the well-being of people and economic development throughout the world" [42].

The issue of sustainable development becomes extremely acute when it is linked to the global trend in urbanization. Sustainability in the context of urban development means a necessity to solve a variety of problems: social, economicenvironmental and management system [43]. Environmental aspect is an important element of sustainable urban development, which includes the issues of air quality conservation, waste management, efficient energy use, water management andgreenery planting.

The main hypothesis of the paper is that promotion of urban greening, in particular in Russia, will lead to significant improvements in economic and social spheres. Greening benefits considerably exceedthe costs for its implementation and maintenance. However, it is necessary to findan economic approach for adequate assessment of the greening benefits. The goal of this article is to determine efficient economic approaches for the assessment of greening benefitsand, additionally, for measurement of government policy in this field. Such approaches might be useful for greening system optimization in urban environment, especially in megacities.

The paper is organized as follows. First, it presents the concept of sustainable urban development. The specific features of urban systems' functioning are mentioned and the 
threats to sustainable development in condition of intense urbanization are presented. The following section discloses the concept and functions of urban greening and provides the evidence of its contribution to all three aspects of sustainable urban development. The main problem of green urban spaces development such as the difficulties in determining its economic feasibility is stated and then a way of valuation the economic value of urban forests is proposed. The paper also provides some illustrative real practice examples of urban greening measurement practices implementation.

\section{SUSTAINABLE URBAN DEVELOPMENT}

The definition of "sustainable development" was introducedby the World Commission on Environment and Developmentwhich determined it as a "development that meets the needs of the present without compromising the ability of future generations to meet their own needs" [1]. The main goal of sustainable development was the long-term stability of the economy and environment [11].

Nowadays the urbanization is the modern tendency globally, so theissues of sustainable urban development become extremely important. According to the United Nations Department of Economic and Social Affairs, in 2050 the world population is projected to be $66 \%$ urban as urban dwellers number is projected to grow by 2.5 billion between 2014 and 2050, with nearly 90 per cent of the increase concentrated in Asia and Africa [44].

On the one hand, cities are the engines of economic growth and innovation [21]. On the other hand, the process of urbanization poses lots of challenges, affecting all the three pillars of sustainable development. Urbanization sharpens the problems of climate change, poverty, unemployment, aging population and the youth bulge, commoditization of land and housing, amplification of different types of crises etc. [41]. Policymakers throughout the world are coming to the conclusion that rapid and unplanned urban growth threatens sustainable development. In turn sustainable urban development will lead to economic and social improvements. The 2030 Agenda for Sustainable Development tackles this challenge through its Sustainable Development Goal 11, which aims to "make cities and human settlements inclusive, safe, resilient and sustainable" [45].

It is also critical to point out that sustainability at the context of urban development means necessity to solve the problems of energy conservation, effective use of resources, public transport system planning, re-use of materials, organic waste composting, the issues of densification and compact building. There are different approaches to solve these problems, that may contribute to sustainable urban development. Among them the promotion of Transition Towns, Fairtrade Towns, Sustainable Cities, Green cities, Eco cities, Livable cities, UN-Compact Cities, the Innovation City, Social Enterprise Cities $[28 ; 10]$. In order to summarize the existing approaches to sustainable urban development United Nations Department of Economic and Social Affairs suggests four pillars that would enhance the sustainability of cities: 1) Social development, 2) Environmental protection, 3) Economic development, and 4) Effective urban governance (Table 1) [43]. 
Alekseeva I., Menshikh D., Kudryavtseva O.V. Greening as an Element of Sustainable Urban Development...

Table 1

Elements of urban sustainability

(Sources: estimated by authors, based on UNDESA, 2013 [43])

\begin{tabular}{|l|l|l|l|}
\hline \multicolumn{4}{|c|}{ Sustainable cities } \\
\hline Social development & Environmental protection & Economic development & $\begin{array}{l}\text { Effective urban govern- } \\
\text { ance }\end{array}$ \\
\hline $\begin{array}{l}\text { Social equity and poverty } \\
\text { reduction }\end{array}$ & $\begin{array}{l}\text { Forest and soil man- } \\
\text { agement }\end{array}$ & Green productive growth & $\begin{array}{l}\text { Decentralization and } \\
\text { planning }\end{array}$ \\
\hline Education and health & Urban greening & $\begin{array}{l}\text { Creation of decent em- } \\
\text { ployment }\end{array}$ & $\begin{array}{l}\text { Increasing civil engage- } \\
\text { ment in governance }\end{array}$ \\
\hline Food and nutrition & $\begin{array}{l}\text { Waste and recycling } \\
\text { management }\end{array}$ & $\begin{array}{l}\text { Production and distribu- } \\
\text { tion of renewable energy }\end{array}$ & $\begin{array}{l}\text { Strengthening civil and } \\
\text { political rights }\end{array}$ \\
\hline $\begin{array}{l}\text { Green housing and } \\
\text { buildings }\end{array}$ & $\begin{array}{l}\text { Sustainable transport } \\
\text { system and energy use }\end{array}$ & $\begin{array}{l}\text { Technology and innova- } \\
\text { tion (R\&D) }\end{array}$ & $\begin{array}{l}\text { Support of local, national, } \\
\text { regional and global links }\end{array}$ \\
\hline $\begin{array}{l}\text { Infrastructure develop- } \\
\text { ment }\end{array}$ & $\begin{array}{l}\text { Water management (in- } \\
\text { cluding fresh water) }\end{array}$ & $\begin{array}{l}\text { Creation of decent em- } \\
\text { ployment }\end{array}$ & $\begin{array}{l}\text { Increasing civil engage- } \\
\text { ment in governance }\end{array}$ \\
\hline $\begin{array}{l}\text { Recreation areas and } \\
\text { community support }\end{array}$ & Air quality conservation & & \\
\hline & $\begin{array}{l}\text { Adaptation to and miti- } \\
\text { gation of climate change }\end{array}$ & & \\
\hline
\end{tabular}

Thus, the sustainable urban development is a balanced progression in three main dimensions: economic, social and environmental with paying special attention to management system development. It includes a variety of issues such as, for example, green housing, air quality conservation, public transport system, water management, greenery planting and others. The importance of these issues cannot be underestimated as the solution of these problems may lead to social and economic improvements.

Now we would like to separately consider such particular element of sustainable environmental urban development as urban greening and discuss its importance and challenges.

\section{GREENING AS A PART OF SUSTAINABLE URBAN DEVELOPMENT}

Urban green spaces development or urban vegetation(greening) is an important part of sustainable urban development. The value of green spaces can be systematized in different ways. We can define the value of green spaces according to spacial, technological, social and cultural dimensions [39].

Urban green spaces play an important role in the ecological aspect of city development. Firstly, it contributes to the sustainable biodiversity conservation by providing a livable area for plant and animal life [15]. Furthermore, plants reduce air pollution and lower noise [6], which influence both ecological situation and living conditions in the area. One of the major functions of vegetation is the thermal performance adjusting, which is reached by reflecting the solar radiation [16] and balancing the temperature, especially in hot, dry areas. The other ecosystem service provided by plants and forests is water retention [19].

The amount of urban green spaces in the nearby environment also contributes to the personal citizens' well-being in several ways. For instance, the green spaces availability favorably influenceson the level of physical health of the inhabitants [20], even 
reducing mortality [13]. Lovasi et al., 2013 [26] has proved that high obesity rate of preschool children in low-income families in NYC is partly caused by lack of green spaces around for leisure and active lifestyle. It was found that trees can contribute to the reduction of workers' stress [25]. It has been also shown that the amount of green space in the living environment and the frequency and length of visits to the forestry and parks are positively associated with the individual mental health and vitality and decrease the level of perceived stress [17].

An important feature of urban green spaces is the provision of a site for communication and recreation. People tend to use green spaces for physical exercises [24] and outdoor communication and activities [8]. Moreover, green spaces not only stimulate social interaction, but also act as a cultural heritage site,contribute to the city identity and enrich aesthetic values [34; 27]. Hence, green spaces satisfy various physical, psychological and social needs of the residents. It can be then concluded that green spaces indirectly low the social tension and stabilize the social situation by increasing the life satisfaction of citizens in general.

The development of urban green spaces faces various challenges. For example, urban vegetation is often of a low priority in both governmental strategies and programs and private sector activities. The reason is that the potential greening benefits are underestimated by authorities and business as there is not enough evidence of the necessity of such practices and, what is more important, its economic value. Because of potential contributors' inability to assess the return on the investment there is often lack of financial sources in the area.

As urban sprawl as a form of urban development has several disadvantages such as low efficiency of energy and resources use, social inequalities and environmental problems [33], more ecological and sustainable cities tend to have more compact or dense forms [30]. However, such forms cause new challenges to urban greening. For example, soil quality is one of the important urban problems (soil is exhausted and less fertile, abounds cables, tubing etc.), which becomes even more severe in dense city environments [36]. Moreover, there are the challenges of both planning new green spaces in compact cities and conserving the existing ones while the infill development [18]. One of the ways to solve the problem of space shortage is roof planting. For instance, the Swedish government and The Delegation for Sustainable cities launched an initiative, promoting urban greening and efficient use of urban space. One of the accomplished projects was the construction of green walls and green roofs in the city Malmö and even creating a Scandinavian Green Roof Association [37].

The other challenge in urbangreening is the difficulties in coordination the needs, requirements and abilities of different parties. Conservation and development of urban green spaces requires a comprehensive approach including the collaborationwith local authorities, inhabitants, who are also divided in several groups by their preferences, civic activists, developers and entrepreneurs. Decision makers need to take into consideration and adequately reflect all the needs, often contradicting [12]. To this point administrative and bureaucratic problems of making and implementing decisions are added, which makes urbangreening a complicated process. 
Thus, urban greening plays an important role in sustainable urban development. Besides mentioned ecological benefits and positive influence on citizens' health and overall quality of life, urban green spaces also contribute to urban design, connecting different parts and scales of the urban landscape [39]. However, there are several challenges for the successful urban green spaces development, such as lack of investment, tendency to dense city forms and coordination of needs of different parties.

\section{ECONOMIC EVALUATION OF URBAN GREENING BENEFITS}

As mentioned above, one of the challenges of urban green spaces development is the lack of financing due to non-obviousness of the returns on such investments. Although the aim of sustainable development is set in almost every modern city's strategical plan, the real implementation of this principle and, in particular, greening, is typically postponed. The reason for it is that the ecological situation is not critical yet and ecological threats are not perceived as urgent, while the benefits from plantings are questionable. Governments prefer to invest in more measurable areas such as transport or education where the direct social benefit of the policies can be easily assessed and presented.

As green areas belong to the category of social goods, they are non-rivalrous and non-excludable. First means that the consumption of the good by one consumer cannot influence the possibility of the other consumer to use the good simultaneously. Second means that non-paying consumer cannot be prevented from using the good. These characteristics make plantings a non-appealing investment for private businesses as at the first glance they do not generate income.

The possible solution for this problem lays in the possibility of evaluating the economic benefits of the plants in the particular area. In reality, each tree carries particular value that can be expressed in the value indicator. Appropriate valuation of the services that green areas provide to the society leads to the amount of green spaces and level of their maintaining which is maximizing the social utility.

As mentioned in the second chapter, there are direct benefits from a green landscape to each resident living in the area, such as health, recreational, social, aesthetic benefits. This fact is reflected in the direct correlation between the quantity and quality of greening in the area and the realty prices, as there is obviously a higher demand for the houses situated in better environmental conditions. Health benefits can be also potentially evaluated through the annual medical costs savings, although the procedure requires certain nontrivial research.

Assessing the profit for a local economy two things should be taken into account. First, the revenue growth of local enterprises and shops, both from the increase in the number of the area visitors coming for leisureand recreation, and from the changes in willingness-to-pay of the residents and visitors. It has been proved that the quality of public environment has a significant impact on the consumer behavior. For instance, Kathleen L. Wolf, 2004 [40] has shown that consumers associate the presence of urban forests in the central retail district with higher visual quality rating of the district. The other study has shown that greenery among other atmospheric characteristics of shopping center influences the consumer behavior and the willingness-to-pay [32]. Second, it can be 
said that green areas contribute to the budget replenishments, as additional consumption generates tax flows to the local budgets.

Ecological value of parks and green spaces can be alsoeconomically evaluated. For instance, one of the valuation objects can be storm water management, slowing the runoff of the water and reducing the load of storm water system, consequently lowing the expenses for its maintaining. Savings due to the reduction in air pollution can be measured by assessing the costs of the air cleaning facilities that would result in the same level of air purification as a certain planting. When calculating the expenses for the cleaner costs of maintenance, service and depreciation should be considered. Total urban greening benefits (B) can be calculated according to the following formula (based on the concept suggested by Kudryavceva et al., 2015 [22]):

$$
B=\sum_{i} \sum_{j}(a+h+p+x)
$$

Where a is the average annual added value of the air enhancement which includes solid particles retention, and pollutant gasesabsorption; h refers to reduction in the average annual water outflow;p reflects the aesthetical value and total convenience of close green area location which is expressed in the realty prices rise; $x$ reflects the local economy profit including additional earnings of shops and elements of infrastructure and additional budget tax revenue; i refers to the tree;j refers to the segment of the woodland.

For conducting the research and data representation, the remote sensing systems are used. For instance, geographical information systems (GIS) are widely used for ecological and economic benefits assessment of urban vegetation. A number of systems is designed to analyze the potential value of urban green space and urban forests based on such technologies or other approaches. Existing approaches of trees valuation would be presented in one of the following chapters.

Thus, the necessity of economic valuation of urban vegetating has been proven. We have suggested a method for valuation of urban greening benefits that would take into account most of the measurable gains, such as ecological, social, aesthetic.

\section{MEASUREMENT OF URBAN GREENING POLICIES}

There are several reasons why timely and credible assessment of urban vegetation practices is necessary. The relevant data about the condition of green areas is required primarily for its conservation, maintaining and improvement [23]. Time series observation taken for one area makes it possible to evaluate the effectiveness of the policies and activities in the field of urban greenery, understand its week points and improve the strategy. Assessment of policies with numerical indicators is useful for informing the population about the results due to its visibility. As indicators demonstrably illustrate the results of local authorities' activities in the area of sustainable development, they can increase public confidence in the government and positively affect the level of civic engagement in urban development practices [2].

There are several approaches for assessment of greening practices, which are commonly used.The first one is inventory method, which comprises two stages: a field stage, including observation of plants and collection the data concerning their overall condition 
and characteristics. On the second stage, the received information is integrated into the database with its further introduction to the registry forprocessing. There is special system of indicators and criteria for assessment of plants status. For instance, inventory method for trees can include individual assessment of the following characteristics: the type of planting, species, age (divided by classes), diameter, height, damages, quality (divided by classes) [23].

Another approach that can be applied is the calculation and analysis of various indexes and indicators reflecting the quality and extent of urban greening. The scheme 1 showsa variety of existing indicators used for assessment the urban greenery status, these include thesize and structure of urban green space, its ecological and social qualities, the accessibility of urban greening and expenditure on its maintenance [4].

\begin{tabular}{|c|c|c|c|c|}
\hline & & $\begin{array}{c}\text { Indicators } \\
\text { of urban greening }\end{array}$ & \multirow[b]{2}{*}{$\checkmark$} & \multirow[b]{2}{*}{$\nabla$} \\
\hline$\nabla$ & $\nabla$ & $\downarrow$ & & \\
\hline $\begin{array}{c}\text { Size } \\
\text { and Structure }\end{array}$ & $\begin{array}{l}\text { Qualitative proper- } \\
\text { ties (ecological) }\end{array}$ & $\begin{array}{c}\text { Social } \\
\text { Functionality }\end{array}$ & Accessibility & Maintenance \\
\hline $\begin{array}{l}\text { Green space } \\
\text { indicator } \\
\text { Surface area of } \\
\text { green structures } \\
\text { in the city (\%) } \\
\text { Extent and num- } \\
\text { ber of forests, } \\
\text { parks, private } \\
\text { gardens, water } \\
\text { areas, green } \\
\text { edges, etc. }\end{array}$ & $\begin{array}{l}\text { Environmental } \\
\text { functionality } \\
\text { (e.g. adsorption } \\
\text { of emissions (e.g. } \\
\text { storm water) and } \\
\text { microclimate) } \\
\text { Biodiversity indi- } \\
\text { cators - occur- } \\
\text { rence of red-listed } \\
\text { species in green } \\
\text { structures (num- } \\
\text { ber of species); } \\
\text { City Biodiversity } \\
\text { index } \\
\text { Protection indica- } \\
\text { tor - number of } \\
\text { and surface are } \\
\text { (ha) of Protected } \\
\text { areas }\end{array}$ & $\begin{array}{l}\text { Number of urban } \\
\text { green spaces } \\
\text { with rest and re- } \\
\text { laxation opportu- } \\
\text { nities, walking } \\
\text { and biking op- } \\
\text { portunities, with } \\
\text { playgrounds for } \\
\text { children; with } \\
\text { sport grounds; } \\
\text { with cultural } \\
\text { events, etc. }\end{array}$ & $\begin{array}{l}\text { Number and per- } \\
\text { centage of inhabi- } \\
\text { tants living no less } \\
\text { than } 300 \text { meters } \\
\text { (walking distance) } \\
\text { from a green } \\
\text { structure above } \\
\text { a certain size } \\
\text { Number and per- } \\
\text { centage of inha- } \\
\text { bitants with } \\
\text { a green structure } \\
\text { in sight }\end{array}$ & $\begin{array}{l}\text { Maintenance } \\
\text { budget per in- } \\
\text { habitant } \\
\text { Percentage } \\
\text { of extensively } \\
\text { managed areas } \\
\text { Percentage } \\
\text { of intensively } \\
\text { managed areas }\end{array}$ \\
\hline
\end{tabular}

Scheme 1. Indicators of urban greening

(Sources: estimated by authors, based on BUUF City Status Reports [4]

For assessing the efficacy of territory use,another indicator such as the coefficient of ecological stability can be used [7]. It is calculated according to the following formula:

$$
K=\frac{\sum\left(P_{i} K_{i}\right)}{\sum P_{i}} K_{p},
$$

where $P$ is the area of the site with the corresponding index of ecological stability; $K$ is the coefficient of ecological stability of the site $I ; K_{p}$ is the coefficient of the morphological stability of the relief (based on the possibility of landslides and mudflows). 
Computing of the green space can be executed through special instruments that calculate area using maps.

It should be also mentioned that trees and other plants can be divided in several groups by their impact to the environment, meaning that some breeds can be more useful in solving particular problems than the others due to the specific features of each type of plant or breed. It is clear then that the individual coefficients for each group of plants can be calculated.

Thus, the assessment of urban greening is necessary not only to conserve, maintain and improve green areas, but also to raise public awareness of urban greening importance and to provide evaluation of the policies and activities in the field of urban greening for their further improvement.As we have shown, there are different approaches for assessment of greening practices, such as inventory method and indicator-based method, which are now actively used by policymakers and communities throughout the world to promote urban greening.

\section{EXAMPLES OF REAL-LIFE PRACTICES OF URBAN GREENING PROMOTION}

One of the main problems of moving towards sustainable urban development is monitoring the process of transformation to the desired state or objective [29]. Communities introduce different sustainability projects and plans concerning urban greening, and use different measurement approaches to monitor the progress. For instance, the trees' inventory was held in the city of Renton in 2009 [9]. This inventory included the calculation of all tree species, their diameters and age groups, their condition and maintenance recommendations. As the result of the assessments, the economic benefits were valuated using the Guide for Plant Appraisal and presented to the public [9]. There are several systems already implemented in the world that measure the economic value of the plantings. One of them is Helliwell System, the method developed and adopted by the Arboricultural Association and the Tree Council in Great Britain that has been widely used since then for various public and private inquiries. The method concentrates on one benefit provided by trees - visual contribution to the landscape. According to the methodology, each plant receives number of points for specific criteria which are then combined to form a final score. The latest can be transformed into money value by multiplying on a conversion factor, which is periodically updated by the Tree Council. Basic factors for assessment are size, expected duration of visual amenity, importance of position, presence of other trees, relation to the setting and form [35]. The next method developed for tree valuation is Capital Asset Value for Amenity Trees (CAVAT) developed by the London Tree Officers' Association (LTOA). There are two versions of the method: Full and Quick, varying in precision and optimal amount of assessed woodland. The approach is based on the idea of a unit value factor, which is determined by the replacement cost of the tree. The basic value, which is derived from a unit value factor and the size of truck, is then adjusted with such factors as location, functionality, social value and some more [35]. The unit value factor is calculated corrected to inflation. The method has been used to assess the required compensation for the trees damaged by the 
firms, the example of which took place in 2007 in London. The other method is I-Tree, the software that was introduced in 2006 and simplified the process of urban forest costs and benefits determination. London's I-Tree eco Project was set up to demonstrate the economic benefits of urban greening in London using I-Tree software. According to the project's report, "London's trees provide at least 133 million pounds of benefits every year in terms of air pollution removal, carbon sequestration and reducing the amount of water going into drains. The project revealed some extra-benefits of urban vegetation such as increase in property value, shade and cooling provision, aesthetic benefits, illnesses' recovery assistance, crime reduction, social cohesion improvement and even provision of fruits and nuts for people,animals and nectar for insects [38]. To illustrate some ways of measurement the GetGreen Columbus project, launched in 2005 in Columbus $\mathrm{OH}$, can be considered. Its goal was to coordinate sustainability efforts in order to reduce waste of resources and improve air and water quality using a variety of means. The results of the different initiatives were presented in the GetGreen Annual Report in 2014 demonstrating remarkable achievements in the field of urban greening [14]. The results were measuredin percentage points: 2014 greenhouse gas emissions have been reduced by $25 \%$, and they were also measured in days: in 2014 , there were no days when air quality reached unhealthy levels compared to 2 days in 2013 and 13 days in 2012.

Although the world community is actively taking steps towards the real-life implementation of sustainable urban development principles, including urban greening promotion, in Russia only a few cities have the resources and perspectives for the realization of sustainable urban development projects [3]. One of the reasons may be the lack of urban planners and landscape architects within the municipal organization [31]. The other reason is the lack of society's interest in the problem of sustainable urban development, especially in its environmental aspect [3]. For instance, in 2000 the Danish Ministry of the Environment started a bilateral environmental aid project in St. Petersburg [31]. The aim of the project was "to 'sow the seeds' for a more strategic approach to planning and management of green spaces in St. Petersburg" by developing a GISbased information system and rising public involvement in the improvement of green areas. However, the project failed to raise public awareness of the importance of urban greening promotion and came to a conclusion, that without the appropriate development of human capital in Russia, urban development projects will simply remain without an audience.

\section{CONCLUSION}

Urban greening is an essential part of sustainable urban development. Smart planning of urban green space may contribute to the improvements in ecological, social and economic spheres of citizens' life, providing good conditions for biodiversity conservation, reducing air pollution, managing temperature balance, increasing citizens' overall satisfaction etc. These benefits, thoroughly evaluated, may pursue the governments, if they tend to postpone the implementation of urban greening principles, to change their stance towards potential returns of their investments. 
Although, as it was mentioned, urban greening may meet some challenges such as the lack of policymakers' attention to the problem of judicious urban planning, communities all over the world increase their engagement in urban vegetation development, setting up a variety of projects aiming to move towards urban sustainability.

One of the ways of encouraging local authorities and business to invest in urban green spaces development is the proper measurement of economic values of the plantings. The paper has offered an approach to such valuation, which is based on the main factors of trees contribution to the city environment, such as ecological, social and economic benefits. The applicability of the theoretical proposal was illustrated by showing the existing systems of trees valuation used worldwide. The measurement of the green spaces policies is necessary which was supported by several arguments. The methods for it were proposed, followed by the corresponding examples.

Provided evidence has shown that there are useful methods and ways of optimizing the system of urban vegetation in big urban agglomerates, in particular in Russia. Further investigation should include more detailed study for the methods most appropriate for a concrete city in each specific case.

(C) I. Alekseeva, D. Menshikh, O.V. Kudryavtseva, 2016

\section{REFERENCES}

[1] Brundtland Commission, 1987. Our common future: Report of the world commission on environment and development. Stockholm, Sweden: United Nations World Commission on Environment and Development.

[2] Bobylev S. Insicators of sustainable development for Russia. Social-ecological technologies. 2012. № 1 .

[3] Bobylev, S., Perelet, R. 2013. Sustainable Development in Russia. Saint Petersburg, Russian Federation: Russian-German Environmental Information Bureau.

[4] BUUF City Status Reports (2003) Baltic University Urban Forum City Status Report V. Project part-financed by the European Union (European Regional Development Fund) within the BSR INTERREG III B Neighbourhood Programme 2003.

[5] Chapple, K., 2015. Planning sustainable cities and regions: Towards more equitable development. Abingdon, Oxon; NewYork: Routledge.

[6] Chaturvedi, A., Kamble, R., Patil, N.G., et al., 2013. City-forest relationship in Nagpur: One of the greenest cities of India. Urban Forest. Urban Green. 12, 79-87.

[7] Chernikov V., Aleksanin R., Golubev A. Agroecology. Kolos, 2000. 536 p.

[8] Chiesura, A., 2004. The role of urban parks for the sustainable city. Landscape Urban Plan. $68,129-138$.

[9] Davey Resource Group, A Division of the Davey Tree Expert Company, 2009. Benson Hill Public Property Tree Inventory and Assessment Report.

[10] El Ghorab H.K., Shalaby H.A., 2015. Eco and Green cities as new approaches for planning and developing cities in Egypt. Alexandria Engineering Journal 55, 495-503.

[11] Emas, R., 2015. The Concept of Sustainable Development: Definitions and Defining Principles.

[12] Ernstson, H., 2013. The social production of ecosystem services: a framework forstudying environmental justice and ecological complexity in urbanized land-scapes. Landsc. Urban Plan. $109,7-17$.

[13] Gascon, M., Triguero-Mas, M., Martínez, D., Dadvand, P., Rojas-Rueda, D., Plasència, A., 2016. Residential green spaces and mortality: a systematic review. Environ. Int. 86, 60-67. 
[14] GetGreen Columbus. Planning Tool Exchange, 2016. Retrieved from $\mathrm{http} / / / \mathrm{www}$.planningtoolexchange.org/project/getgreen-columbus.

[15] Goddard, M.A., Dougill, A.J., Benton, T.G., 2010. Scaling up from gardens: biodiversity conservation in urban environments. Trends Ecol. Evol. 25, 90-98.

[16] Gomez, F., Gil, L., Jabaloyes, J., 2004. Experimental investigation on the thermal comfort in the city: relationship with the green areas, interaction with the urban microclimate. Build. Environ. 39, 1077-1086.

[17] Grahn, P., Stigsdotter, U.A., 2003. Landscape planning and stress. Urban For Urban Greening $2(1), 1-18$.

[18] Haaland C., Konijnendijk van den Bosch C., Challenges and strategies for urban green-space planning in cities undergoing densification: A review, Urban Forestry \& Urban Greening 14 (2015) 760-771.

[19] Hall, T., 2010. Goodbye to the backyard? The minimization of private open space in the Australian outer-suburban estate. Urban Policy Res. 28, 411- 433.

[20] Hartig, T., Mitchell, R., de Vries, S., Frumkin, H., 2014. Nature and health. Annu. Rev. Public Health 35, 207-228.

[21] Keivani R., 2010. A review of the main challenges to urban sustainability, International Journal of Urban Sustainable Development 1:1-2, pp. 5-16.

[22] Kudryavtseva O., Bobylev S., Solovyeva S., Indicators of sustainable development for Russia: urban dimension. On the way tosustainable development of Russia. 2015. 74. P. 16-23.

[23] Kulakova S. Assesment of urban plantings condition. Geographical vestnik. 2012. № 4 (23).

[24] Lee, A.C.K., Maheswaran, R., 2011. The health benefits of urban green spaces: a review of the evidence. J. Public Health (Oxf.) (33), 212-222.

[25] Lottrup, L., P. Grahn, and U.K. Stigsdotter. 2013. Workplace Greenery and Perceived Level of Stress: Benefits of Access to a Green Outdoor Environment at the Workplace. Landscape and Urban Planning 110:5-11.

[26] Lovasi, G.S., Schwartz-Soicher, O., Quinn, J.W., et al., 2013. Neighborhood safety and green space as predictors of obesity among preschool children from low-income families in New York City. Prev. Med. 57, 189-193.

[27] Mell, C., 2009. Can green infrastructure promote urban sustainability? Eng. Sustainability $162,23-34$.

[28] Mössner, S. 2016. Sustainable Urban Development as Consensual Practice: Post-Politics in Freiburg, Germany, Reg. Stud. 50, 971-982.

[29] Musakwa, W. \& Van Niekerk, A. Environ Dev Sustain (2015) 17: 547. doi: 10.1007/s10668014-9560-7.

[30] OECD, 2012. Compact City Policies: A Comparative Assessment, OECD Green Growth Studies. OECD Publishing, Paris.

[31] Nilsson K., Akerlund U., Konijnendijk C., Alekseev A., Caspersen O., Guldager S., Kuznetsov E., Mezenko A., Selikhovkin A., 2007. Implementing urban greening aid projects - The case of St. Petersburg, Russia // Urban Forestry \& Urban Greening № 6.

[32] Op Heij T.J.P. (Tim), 2012. Environmental influences on consumer behaviour, October 2012, Eindhoven.

[33] Power, A., 2001. Social exclusion and urban sprawl: is the rescue of cities possible? Reg. Stud. 35, 731-742.

[34] Priemus, H., Rodenburg, C.A., Nijkamp, P., 2004. Multifunctional urban land use: a new phenomenon? A new planning challenge? Built Environ. 30, 269-273.

[35] Sarajevs V., Street tree valuation systems, Research note, Forestry Commission England, 2011.

[36] Tian, Y., Jim, C.Y., Tao, Y., 2012. Challenges and strategies for greening the compact city of Hong Kong. J. Urban Plann. Dev. 138, 101-109.

[37] The Delegation for Sustainable Cities, 2012. Sustainable urban development projects: Projects that have received financial support from the Delegation for Sustainable Cities. 
[38] Valuing London's Urban Forest: Results of the London i-Tree Eco Project, Treeconomics London, 2015.

[39] Wlodarczyk. D. (ed.), 2007. Green Structure in Development of the Sustainable City. Baltic University Urban Forum. Urban Management Guidebook V. Baltic University Press, Uppsala.

[40] Wolf Kathleen L. Trees and business district preferences: a case study of Athens, Georgia, U.S. / International Journal of Arboriculture 30(6). November 2004. P. 336-346.

[41] UN Habitat (United Nations Human Settlements Programme), 2015. Global Country Activities Report: 2015 - Increasing Synergy for Greater National Ownership.

[5] UN General Assembly, 1972. United Nations Conference on the Human Environment.

[6] UNDESA (United Nations, Department of Economic and Social Affairs), 2013. An Integrated Strategy for Sustainable Cities. UN-DESA Policy Brief No. 40.

[7] UNDESA (United Nations Department of Economic and Social Affairs), 2014. World Urbanization Prospects: The 2014 Revision. (New York: 2014).

[8] UNDESA (United Nations Department of Economic and Social Affairs), 2016. Global Sustainable Development Report 2016, NewYork, July.

\title{
ОЗЕЛЕНЕНИЕ КАК ЭЛЕМЕНТ УСТОЙЧИВОГО ГОРОДСКОГО РАЗВИТИЯ: ОЦЕНКА ЭКОНОМИЧЕСКИХ ВЫГОД, ИЗМЕРЕНИЕ РЕЗУЛЬТАТОВ ПОЛИТИКИ И ПРИМЕРЫ ИЗ ПРАКТИКИ
}

\author{
Ю.С. Алексеева, Д.А. Меньших,
} О. В. Кудрявцева

Московский государственный университет имени М.В. Ломоносова Ленинские горы, 1, Москва, Россия, 119991

Статья показывает важность городского озеленения как одного из средств достижения целей устойчивого городского развития. Авторами представлены экологические, социальные, культурные, пространственные выгоды от развития городского озеленения, а также выделены основные ограничения к развитию озеленения в условиях крупного города. Показано, что оценка экономической выгоды лесов, а также адекватное измерение результатов политики в области озеленения играют важную роль в процессе реализации принципов устойчивого городского развития. Статья представляет существующие методы оценки озеленения и иллюстрирует их внедрение на примерах из российской и зарубежной практики.

Ключевые слова: устойчивое городское развитие, городское озеленение, изменение зеленых зон, проблемы и задачи городов 